\title{
触 New Disease Reports \\ First report of Phytophthora ilicis causing twig blight on holly in Spain
}

\author{
C. Pintos*, C. Rial, O. Aguín and J.P. Mansilla
}

Estación Fitopatolóxica Do Areeiro. Deputación Pontevedra. Unity associated to CSIC. Subida a la Robleda s/n. 36153. Pontevedra, Spain

*E-mail: cristina.pintos@depo.es

Received: 23 Feb 2012. Published: 05 Nov 2012. Keywords: Ilex spp., leaf spots, Phytophthora ramorum, ornamental plants

During Phytophthora ramorum monitoring surveys at nurseries, parks and public gardens, a range of ornamental plants susceptible to infection with Phytophthora were extensively surveyed. In 2011, during these surveys in Santiago de Compostela (Galicia, NW Spain), several holly plants (Ilex aquifolium) were observed exhibiting black leaf spots, defoliation, twig blight, cankers and shoot dieback. Excised tissue from the leading edge of lesions on twigs and stems was plated on V8 agar semi-selective medium (Erwin \& Ribeiro, 1996) and incubated for four days at $20^{\circ} \mathrm{C}$ in the dark. A Phytophthora sp. was consistently isolated. This was transferred to carrot agar (CA) and potato dextrose agar (PDA) (Fig. 1). Isolates exhibited optimal growth at $16-18^{\circ} \mathrm{C}$ and maximum growth at $25^{\circ} \mathrm{C}$. Sporangia formed sympodially, were semipapillate, caducous with medium length pedicels 5-15 $\mu \mathrm{m}$ long (Fig. 2a) and had a length/width ratio of 1.2-1.6. Chlamydospores were not observed. Isolates were homothallic. Oogonia ranged from 17-27 $\mu \mathrm{m}$ in diameter (average 22.67 $\mu \mathrm{m})$. Oospores were plerotic 14.6-23.6 $\mu \mathrm{m}$ in diameter (Fig. 2b-d). Antheridia were amphigynous, round, and occasionally elongated (Fig 2b-d). Based on these morphological characters, cultures were identified as Phytophthora ilicis (Buddenhagen \& Young, 1957). Identity was confirmed by DNA sequences analysis. DNA from isolates was extracted and the internal transcribed spacer (ITS) and translation elongation factor 1 alpha (EF-1 alpha) gene regions were amplified using primers DC6, ITS4 and ITS6 (Cooke et al., 2000) and ELONGF1-ELONGR1 (Kroon et al., 2004). PCR amplicons were sequenced and deposited in GenBank (Accession Nos. JQ609277 and JQ609278, respectively). Comparison of the sequences with others sequences available in GenBank showed $100 \%$ homology with those previously identified as P. ilicis (FJ8001947 and AY564127).

A pathogenicity test of one representative isolate of $P$. ilicis was conducted using five detached stems of holly. A shallow wound was made with a scalpel on the middle of the stem. A $5 \mathrm{~mm}$ mycelial plug, from the margin of a seven-day-old culture growing on V8 agar, was inserted in every wound and sealed with Parafilm. The inoculated shoots were maintained at room temperature and $75 \%$ humidity. After 10 days stem blackened cankers and defoliation were observed (Fig. 3). Control stems, inoculated with sterile V8 agar, remained symptomless. P. ilicis was re-isolated from all inoculated stems but not from controls. To our knowledge this is the first report of Phytophthora ilicis causing leaf and twig blight on Ilex in Spain. P. ilicis is an invasive aerial Phytophthora characteristically found in cool temperate regions and it is host specific on holly. All cultivars of $I$. aquifolium are susceptible, although some other Ilex species and hybrids show resistance (Hall, 1991). P. ilicis was first reported and described in the western United States and is also recorded in Canada, U.K, the Netherlands and France.

\section{References}

Buddenhagen IW, Young RA, 1957. A leaf and twig disease of English holly caused by Phytophthora ilicis n.sp. Phytopathology 47, 95-101.

Cooke DEL, Drenth A, Duncan JM, Wagels G, Brasier CM, 2000. A molecular phylogeny of Phytophthora and related Oomycetes. Fungal Genetics and Biology 30, 17-32.

[http://dx.doi.org/10.1006/fgbi.2000.1202]

Erwin DC, Ribeiro OK, eds, 1996. Phytophthora Diseases Worldwide. St. Paul, Minnesota, USA: APS Press.

Hall G, 1991. Phytophthora ilicis. IMI Descriptions of Fungi and Bacteria No.1064. Mycopathologia 115, 225-226. [http://dx.doi.org/10.1007/BF00462231]

Kroon LPNM, Bakker FT, van den Bosch GBM, Bonants PJM, Flier WG. 2004. Phylogenetic analysis of Phytophthora species based on mitochondrial and nuclear DNA sequences. Fungal Genetics and Biology 41,766-782. [http://dx.doi.org/10.1016/j.fgb.2004.03.007]

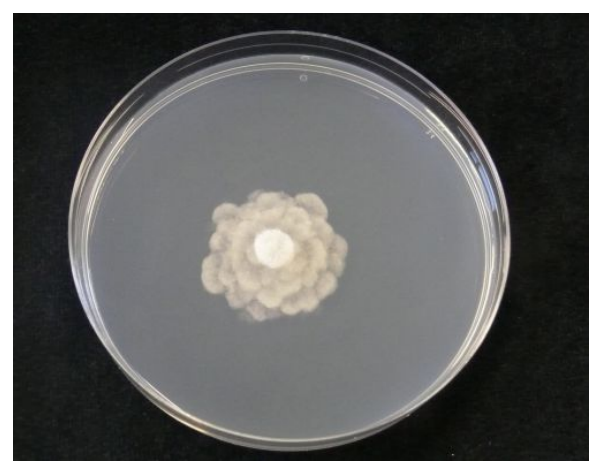

Figure 1

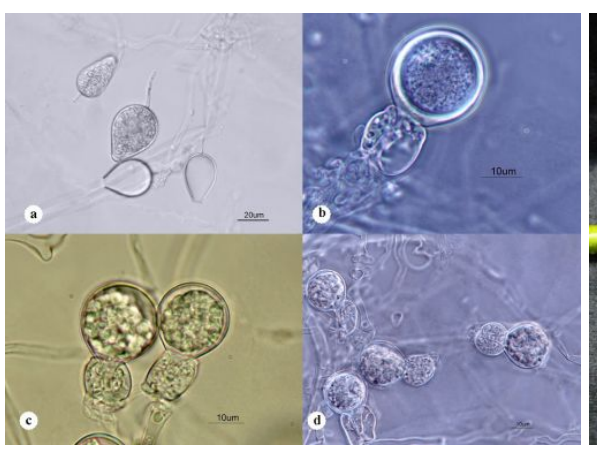

Figure 2

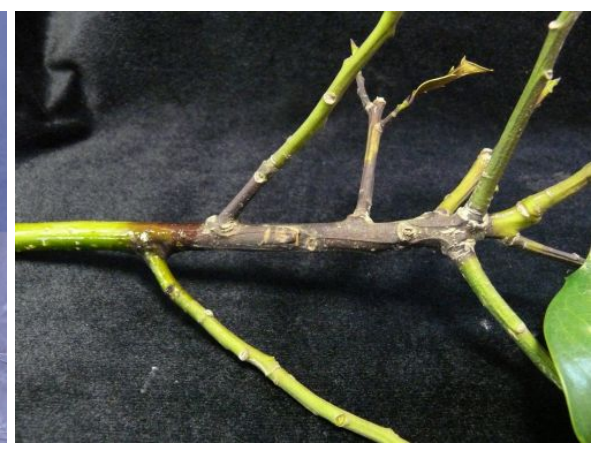

Figure 3

To cite this report: Pintos C, Rial C, Aguín O, Mansilla JP, 2012. First report of Phytophthora ilicis causing twig blight on holly in Spain. New Disease Reports 26, 16. [http://dx.doi.org/10.5197/j.2044-0588.2012.026.016]

(c) 2012 The Authors This report was published on-line at www.ndrs.org.uk where high quality versions of the figures can be found. 